http://dx.doi.org/10.18778/1643-0700.17.05

\author{
Elżbieta JARCZAK* Agnieszka LITWA**
}

\title{
KOŚCIÓŁ ŚW. WAWRZYŃCA W ROSSOSZYCY - ZARYS HISTORII I STAN OBECNY ${ }^{1}$
}

Streszczenie. Modrzewiowy kościół parafialny pod wezwaniem św. Wawrzyńca w Rossoszycy pochodzi z końca XVIII w. i jest jednym z cenniejszych zabytków na ziemi szadkowskiej. W okresie minionych ponad dwustu lat kościół był wielokrotnie remontowany. Przypadająca na 2016 r. rocznica 600-lecia powołania parafii rossoszyckiej stanowiła inspirację do pojęcia w 2014 r. kolejnego, gruntownego (trwającego do dziś) remontu tego zabytkowego obiektu. Obecny kościół jest trzecim wystawionym na tym miejscu, pierwszy istniał już na początku XV w., w latach 1770-1773, na jego miejscu wzniesiono drugi kościół, który jednak już w 1781 r. spłonął wraz z całym inwentarzem. Trzecia świątynia, wybudowana w 1783 r., przetrwała do dziś. W artykule, obok historii kościoła, przedstawiono zakres prowadzonych od 2014 roku prac remontowych i konserwatorskich.

Słowa kluczowe: parafia Rossoszyca, wieś Rossoszyca, kościół pw. św. Wawrzyńca w Rossoszycy.

Wpisany na listę zabytków w rejestrze Narodowego Instytutu Dziedzictwa ${ }^{2}$ modrzewiowy kościół parafialny pw. św. Wawrzyńca w Rossoszycy położony jest nad stawem, na niewielkim wzniesieniu, w otoczeniu okazałych lip. Budowę nowej świątyni - na miejscu poprzedniej, którą strawił pożar - podjęto 29 listopada 1783 r. z inicjatywy fundatorki, Maksymy z Szembeków Pstrokońskiej, dziedziczki Rossoszycy, wdowy, chorążyny piotrkowskiej³. Już trzy lata

* Elżbieta Jarczak, dyrektor Miejskiej i Gminnej Biblioteki Publicznej w Szadku, ul. Prusinowska 4, 98-240 Szadek, e-mail: elajarczak@o2.pl.

** Agnieszka Litwa, mgr historii sztuki, Katedra Historii Sztuki Uniwersytetu Łódzkiego, ul. Jana Lechonia 4/27, 95-100 Zgierz, e-mail: agn.mad_hatter@wp.pl

1 Artykuł powstał na podstawie pracy licencjackiej Agnieszki Litwy, Kościół św. Wawrzyń$c a w$ Rossoszycy. Monografia, Uniwersytet Łódzki, Wydział Filozoficzno-Historyczny, Łódź 2014 (za zgodą autorki).

2 Narodowy Instytut Dziedzictwa (dalej: NID), Rejestr zabytków nieruchomych, województwo łódzkie, nr rej. 839 z 28 grudnia 1967 r.

3 Archiwum Diecezjalne we Włocławku (dalej: ADW), sygn. Archiwum Arcybiskupów Gnieźnieńskich (dalej: AAG). Wiz. 80, Visitatio decanalis [...] in Decanatu Lutomiriensi, Archidiaconau Uniejoviensi existentium [...] per me [Vincentim Kępiński] anni 1786-ti expedita, facta et descripta, s. 10. 
później w dokumentach z wizytacji parafii (1786 r.) znajdujemy opis mówiący, iż kościół jest w całości drewniany, umieszczony na murowanych fundamentach i prawdziwie przyzwoity, a w tym dekanacie wyjatkowy ${ }^{4}$.

W okresie minionych ponad 200 lat kościół był wielokrotnie remontowany. Przypadająca na 2016 r. rocznica 600 -lecia powołania parafii rossoszyckiej stanowiła inspirację do pojęcia w 2014 r. kolejnego, gruntownego (trwającego do dziś) remontu tego zabytkowego obiektu.

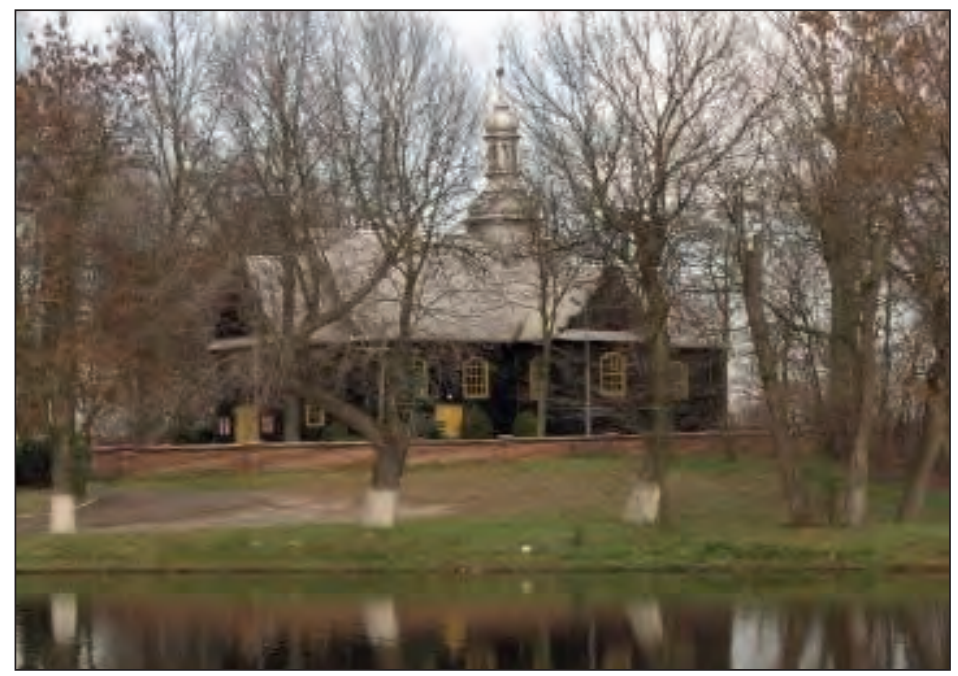

Fot. 1. Kościół w Rossoszycy (2010 r.)

Źródło: http://www.kosciolydrewniane.pl/pages/drewniane/rossosz.html, zdjęcie M. Rychlik [dostęp 23.03.2017]

\section{ROSSOSZYCA - RYS HISTORYCZNY WSI}

Najstarsza wzmianka odnosząca się do Rossoszycy pochodzi z 1390 r. W księgach ziemskich sieradzkich ${ }^{5}$ pojawił się zapis o wsi, której właścicielem był Nicolaus de Roszoszki. Nazwa wsi w różnych dokumentach jest odmiennie zapisywana, np. w 1395 r. pojawia się jako Rossossicza ${ }^{6}$, a w 1416 r. odnajdujemy nazwę - Rossoszyca?.

W 1579 r. wieś była własnością Jakuba Roszowskiego, Stanisława Wysockiego oraz Doroty Sierakowskiej ${ }^{8}$, zaś w XVIII w. przeszła w ręce rodu Pstro-

4 Tamże.

5 Por. S. Zajączkowski, S.M. Zajączkowski, Materiaty do stownika geograficzno-historycznego dawnych ziem tęczyckiej i sieradzkiej do 1400 r., cz. 2, Wrocław 1970, s. 72.

6 Tamże.

7 J. Łaski, Liber beneficiorum archidioecesis gnesnensis, t. 1, oprac. J. Łukowski, J. Korytkowski, Gniezno 1880-1881, s. 388.

8 P. Tameczka, Zbiór informacji z dostępnych publikacji/prasy na temat historii wsi Rossoszyca, http://sieradzkiewsie.blogspot.com/2013/05/rossoszyca.html [dostęp: 9.03.2017]. 
końskich. W 1873 r. właścicielem majątku został Adam Nencki, kupując dobra w drodze publicznej licytacji. Z zakupionych dóbr wyodrębnił wieś i folwark, a pozostały majątek podzielił na pięć części. W 1912 r. Rossoszyca była już własnością spadkobierców Mikołaja Zabłockiego9 i uwłaszczonych włościan.

Wieś Rossoszyca mocą ukazu carskiego z dnia 2 marca 1864 r. została przekształcona w Gminę. Niestety, nie zachowały się najstarsze dokumenty wytworzone przez ten urząd ${ }^{10}$. W latach 1926-1954 w Rossoszycy mieściło się Prezydium Gminnej Rady Narodowej ${ }^{11}$. Tę funkcję administracyjną Rossoszyca utraciła 29 września 1954 r. wraz z wejściem w życie reformy wprowadzającej Gromady (w miejsce wcześniej obowiązującego podziału administracyjnego kraju) ${ }^{12}$. W latach 1954-1972 Rossoszyca była siedzibą Prezydium Gromadzkiej Rady Narodowej (jednej z 8759 gromad na obszarze Polski) ${ }^{13}$. Kolejna reforma administracji terytorialnej, wprowadzona 1 stycznia 1973 r., przywracająca podział na gminy, oznaczała całkowitą utratę funkcji administracyjnej przez Rossoszycę. Wieś i otaczający ją obszar włączono do gminy Warta (województwo łódzkie) ${ }^{14}$.

\section{PRZYNALEŻNOŚĆ TERYTORIALNO-ADMINISTRACYJNA PARAFII W ROSSOSZYCY}

Na przestrzeni wieków parafia rossoszycka kilkukrotnie zmieniała swoją przynależność do jednostek administracji kościelnej. W okresie staropolskim należała do archidiecezji gnieźnieńskiej ${ }^{15}$. Liber beneficiorum prymasa Łaskiego (zawierający jeden $\mathrm{z}$ najwcześniejszych wykazów dekanatów $\mathrm{w}$ archidiecezji gnieźnieńskiej) wymienia 14 dekanatów zgrupowanych w trzech archidiakonatach. W położonym na ziemi sieradzkiej archidiakonacie uniejowskim ${ }^{16}$ parafia Rossoszyca została wymieniona jako przynależna do dekanatu uniejowskiego ${ }^{17}$.

Reorganizacja struktur terytorialnych archidiecezji gnieźnieńskiej w drugiej połowie XVIII w. doprowadziła do utworzenia nowego dekanatu lutomierskie-

9 http://sieradzkiewsie.blogspot.com/2015/03/elzbieta-halina-nejman-majatki-szlachta.html, http://tpzw.zdunskawola.pl/?herbarz-szl ... -online,41 [dostęp 9.03.2017].

10 W zasobach Archiwum Państwowego w Łodzi, Oddział w Sieradzu, przechowywane są Akta gminy Rossoszyca z lat 1945-1954 (zespół nr 24).

11 Główny Urząd Statystyczny w Warszawie, Województwa centralne $i$ wschodnie Rzeczypospolitej Polskiej, podział na gminy wedtug stanu z dnia 1 IV 1933 roku, Książnica - Atlas, Lwów 1933.

12 Dz.U. 1954, nr 43, poz. 191.

13 Podziat Administracyjny Polski Ludowej, Urząd Rady Ministrów, Biuro do Spraw Prezydiów Rad Narodowych, Warszawa 1956.

14 Dz.U. 1972, nr 49, poz. 312.

15 B. Ulanowski, Wizytacje dóbr arcybiskupstwa gnieźnieńskiego i kapituły gnieźnieńskiej z XVI wieku, Kraków 1920.

${ }_{16}$ M. Aleksandrowicz, Gnieźnieńska Archidiecezja. Organizacja terytorialna. Dekanaty, [w:] Encyklopedia Katolicka, t. 5, Lublin 1989, kol. 1182.

17 J. Laski, Liber beneficiorum ..., s. 388. 
$\mathrm{go}^{18}$, w skład którego włączono także parafię w Rossoszycy. W okresie zaborów, na mocy bulli papieża Piusa VII z 30 czerwca 1818 r., dekanat lutomierski został włączony do diecezji kujawsko-kaliskiej w oficjałacie kaliskim ${ }^{19}$. Do tej nowo powstałej diecezji włączono 273 parafie archidiecezji gnieźnieńskiej ${ }^{20}$. W konsekwencji (dokonywanej pod presją władz zaborczych) reorganizacji, z dniem 1 stycznia 1868 r. w diecezji kujawsko-kaliskiej zniesiono 14 dekanatów (pozostawiając ich jedynie 13$)^{21}$. Parafia Rossoszyca w wyniku tych zmian znalazła się w dekanacie sieradzkim ${ }^{22}$.

I wojna światowa przyniosła kolejną reformę administracji kościelnej - 1 stycznia 1917 r. ustanowiono nową sieć dekanalną w diecezji kujawsko-kaliskiej, a parafię w Rossoszycy włączono do reaktywowanego (zlikwidowanego w 1868 r.) dekanatu szadkowskiego ${ }^{23}$.

Od 1925 r. parafia Rossoszyca przynależy do diecezji włocławskiej, utworzonej na terenach dawnej diecezji kujawsko-kaliskiej.

\section{HISTORIA KOŚCIOŁA}

Pierwszy kościół w Rossoszycy istniał już ok. 1400 r. Jego fundatorem był Marcin - dziedzic Rossoszycy, znany fundator kościołów drewnianych, który poległ w bitwie pod Grunwaldem ${ }^{24}$. Istnienie kościoła potwierdza zapis w aktach Konsystorza Gnieźnieńskiego dotyczący sporu plebana Wojciecha z Rossoszycy z Jakóbem plebanem z Czarnocina o dziesięciny w Kale w 1416 r. ${ }^{25}$ Liber beneficiorum prymasa Jana Łaskiego z początku XVI w. wymienia wśród parafii archidiecezji gnieźnieńskiej Rossoszycę - wieś dziedziczną szlachecką, a w niej kościół pw. św. Wawrzyńca ${ }^{26}$. Odnotowanie tego faktu w księdze beneficjów stało się dla późniejszych wizytatorów bardzo znaczące, gdyż nadawali mu rangę dokumentu erekcyjnego ${ }^{27}$, pisząc: nie masz [...] Dokumentów Kościelnych oprócz

18 M. Aleksandrowicz, Gnieźnieńska Archidiecezja..., kol. 1182.

19 Włocławska diecezja, [w:] Encyklopedia Kościelna podtug teologicznej encyklopedii Wetzera $i$ Weltego z licznymi jej dopetnieniami wydana przez x. Michała Nowodworskiego, t. 32, Płock 1913, s. 60.

20 B. Kumor, Ustrój i organizacja Kościoła polskiego w okresie niewoli narodowej (1772-1918), Kraków 1980, s. 204, 207.

21 Tamże, s. 564-566.

22 ADW, Mapa diecezji kujawsko-kaliskiej ułożona przez x. Bernarda Gratowskiego kapucyna w Zakroczymiu 1887 r.

23 S. Zdzitowiecki, Rozporządzenia diecezjalne. 1. Nowy podziat dekanatów, „Kronika Diecezji Kujawsko-Kaliskiej" 1917, nr 1, s. 3.

24 A. Ruszkowski, Sieradz i okolice, Towarzystwo Przyjaciół Sieradza, Sieradz 2000, s. 100.

25 J. Łaski, Liber beneficjorum ..., s. 388.

26 ADW, sygn. AAG. Wiz. 80, Visitatio decanalis..., s. 10.

27 ADW, AAG. Wiz. 73, Wizyta generalna do Decanatów Radomskiego, Brzeźnickiego i Lutomierskiego [w Archidiakonacie Uniejowskim] delegowanego wizytatora roku Pańskiego 1779 odprawiona, s. 501. 
Erekcyi czyli [...] Joannis de Lasco wizyty ex Archivo Capituli Metropolitani Gnesnensis wyiętey. Opis pierwszej świątyni, zawarty w wizytacji archidiakonatu uniejowskiego z $1683 \mathrm{r}^{28}$ przedstawia ją jako kościół drewniany, posiadający trzy pozłacane ołtarze z drewna. W ołtarzu głównym był wizerunek Koronacji Najświętszej Maryi Panny, natomiast w ołtarzach bocznych znajdowały się wizerunki św. Antoniego i Najświętszej Maryi Panny. W opisie wzmiankowana jest także drewniana chrzcielnica ustawiona w rogu kościoła. Następna wizytacja, w $1761 \mathrm{r}^{29}$, opisuje kościół jako mocno zniszczony. Świątynia ma zgniłe fundamenty, spalone ściany, zniszczony dach. Zniszczenia musiały być uznane za poważne, skoro sugerowano wybudowanie nowej świątyni.

Drugi kościół został wzniesiony w latach 1770-1773. Jego wygląd udokumentowany został $\mathrm{w}$ dokumentach $\mathrm{z}$ wizytacji dekanalnej przeprowadzonej w 1779 r..$^{30}$ Nowo wystawiona świątynia założona była na planie krzyża, pokryta dachem gontowym z sygnaturką. Wewnątrz były trzy ołtarze: pierwszy wielki - św. Wawrzyńca, pod którego tytutem jest kościót, drugi po prawej stronie NMP Częstochowskiej, trzeci po lewej stronie św. Antoniego, wszystkie stare bo [przeniesione] ze starego kościoła. Nowy kościół wkrótce uległ zniszczeniu. Spłonął w pożarze, który wybuch 9 czerwca 1781 r. ${ }^{31}$ Wizytacja parafii z 1786 r. podaje, że w sobotę przed Zesłaniem Ducha Świętego kościół niespodziewanie spłonął, a wraz z nim wszystkie sprzęty, ołtarze i dekoracje ${ }^{32}$.

Budowę trzeciego kościoła rozpoczęto 29 listopada 1783 r. Fundatorką świątyni była Maksyma z Szembeków Pstrokońska, dziedziczka Rossoszycy, wdowa, chorążyna piotrkowska ${ }^{33}$. W tym miejscu należy wyjaśnić pewną nieścisłość, którą spotyka się w wielu (prawie wszystkich) opracowaniach na temat fundatorów drugiego i trzeciego kościoła w Rossoszycy. Pojawia się tam postać Bogumiła Budzisz-Pstrokońskiego, dziedzica Rossoszycy, chorążego piotrkowskiego $^{34}$. Informacje te należy jednak uznać za błędne, gdyż mężem Maksymy z Szembeków Pstrokońskiej był Franciszek Budzisz-Pstrokoński, starosta szadkowski, chorąży większy piotrkowski w latach 1746-176135, natomiast Bogumił

28 ADW, sygn. AAG. Wiz. 8, Acta visitationis Archidiaconatus Vnieioviensis [...] in anno Dni 1683-tio felicitier expeditae, s. 56.

29 ADW, sygn. AAG. Wiz. 59, Opus biennale visitationum [generaliom] Archidiaconatus Vniejovien[sis] [...], Territorij Vielunensis, z lat 1761-1763, s. 193.

30 ADW, sygn. AAG. Wiz. 73, Wizyta generalna ..., s. 405.

31 S. Librowski, Repertorium akt wizytacji kanonicznych dawnej Archidiecezji Gnieźnieńskiej, cz.1: Akta przechowywane w Archiwum Diecezjalnym we Włocławku, z. 3: Archiwa Biblioteki i Muzea Kościelne, t. 30, s. 95.

32 ADW, sygn. AAG. Wiz. 80, Visitatio decanalis..., s. 10.

33 Tamże.

34 ADW, Rubrycela dyecezyi kujawsko-kaliskiej z r. 1877, f. 54; po niej powtarza się nota wydawcy do Liber beneficiorum Jana Laskiego, s. 388; Rossoszyca, [w:] Stownik geograficzny Królestwa Polskiego, red. B. Chlebowski, W. Walewski, Warszawa 1888, t. IX, s. 776; A. Ruszkowski, Sieradz, s. 100; „Rocznik Diecezji Włocławskiej” 1991, 2001, s. 548, 817.

35 A. Gąsiorowski, Urzędnicy województw tęczyckiego i sieradzkiego XVI-XVIII w. Spisy, Kórnik 1993, s. 110. 
był synem Maksymy i Franciszka ${ }^{36}$. Brak dokumentów, które wskazywałyby na fakt, że Bogumił pełnił funkcję chorążego piotrkowskiego. Nie ma jego nazwiska w spisie urzędników ${ }^{37}$. Można więc domniemywać, że był tak tytułowany przez pamięć na nieżyjącego ojca (Franciszek zm. ok. 1767 r.). Prawidłową genealogię rodziny Pstrokońskich znajdziemy w artykule Rafała Bogusławskie$\mathrm{go}^{38}$. O Bogumile jako fundatorze wspomina się dopiero w XIX w.

Nowy kościół, opisany w wizytacji z 1786 r. ${ }^{39}$, określany jest jako budowla wyjątkowa w tym dekanacie, drewniana, ale umieszczona na murowanych fundamentach. Uznaje się, że był on podobny do poprzedniego, co może sugerować, iż został zbudowany według tego samego planu i przez tego samego budowniczego. Potwierdza to kopia dokumentu z 1784 r., w której upamiętnia się zasadzenie bani z krzyżem na wieży przez Ignacego Grygla, architekta tego i przeszłego kościoła budownika, a w tutejszych przyległych województwach więcej niz trzydziestu kościołów stanowiciela ${ }^{40}$.

Budowla wzniesiona w 1783 r. w miejscu poprzedniego kościoła, w niezmienionej formie zachowała się do dnia dzisiejszego.

\section{OPIS BRYŁY KOŚCIOŁA}

Kościół w Rossoszycy jest budowlą orientowaną, drewnianą, konstrukcji zrębowej, oszalowaną i zbudowaną na planie krzyża łacińskiego. Posiada trójnawowy korpus z dwiema prostokątnymi kaplicami po bokach, które tworzą rodzaj ramion transeptu oraz wyodrębnione prezbiterium, zamknięte wielobocznie. Od strony zachodniej przylega doń obszerna przybudówka mieszcząca kruchtę w przyziemiu i chór muzyczny nad nią. Zakrystia umieszczona jest wzdłuż prezbiterium, za północną kaplicą. W zewnętrznej bryle kościoła wyodrębniono prostokątny korpus, poprzedzony nieco węższą przybudówką kruchty. Na osi całość zamyka węższe i niższe od korpusu, zamknięte trójbocznie prezbiterium. Skrzyżowanie nawy i pseudotranseptu akcentuje sygnaturka. Zachodnia ściana przybudówki kruchty stanowi główną, dwukondygnacyjną fasadę kościoła. Na jej kompozycję w dolnej części składają się: umieszczony na osi portal oraz dwa symetrycznie umieszczone okna na chór. Fasadę wieńczy dekoracyjny szczyt z oknem na jego osi. Kościół posiada dwuspadowy dach pokryty gontem, osobno dla pomieszczeń kruchty, korpusu i prezbiterium. Nad zakrystią znajduje się dach pulpitowy.

${ }^{36}$ K. Niesiecki, Herbarz Polski. Dodatek do Herbarza Polskiego, Lipsk 1839-1846, s. 371 (genealogia Pstrokońskich herbu Budzisz).

37 A. Gąsiorowski, Urzędnicy województw..., s. 111.

38 R. Bogusławski, Tajemniczy portret - przyczynek do biografii starosty Szadkowskiego Franciszka Budzisz-Pstrokońskiego, „Biuletyn Szadkowski” 2007, t. 7, s. 111-124.

39 ADW, sygn. AAG. Wiz. 80, Visitatio decanalis..., s. 10.

40 Kopia dokumentu odnalezionego w październiku 2014 r. podczas wymiany pokrycia dachowego na kościele. W bani wieńczącej sygnaturkę znajdowały się dokumenty z lat 1784 , 1860 i 1887. 


\section{PRACE KONSERWATORSKIE I REMONTY KOŚCIOŁA W XIX-XX WIEKU}

O przebiegu remontów i konserwacji mówią zarówno dostępne źródła historyczne, jak i przeprowadzone w ostatnich latach badania konserwatorskie oraz ekspertyzy.

W 1860 r. za kolatora Władysława Zaręby-Cieleckiego oraz jego żony Adaminy z Cieleckich Pstrokońskiej odnowiono wieżę i obito ją cynkiem ${ }^{41}$. Był to dar dla opiekującego się w tym czasie świątynią bernardyna z Warty, ks. Edmunda Gumkowskiego.

W Przegladzie Katolickim z 1869 r. znalazła się wzmianka: W Rossoszycy, dawniej pustym kościótku, niemajacym proboszcza od lat stu, a obstugiwanym tylko przez kapłana z klasztoru księży Bernardynów z Warty, dzisiejszy administrator, ks. Kaniewski Aloizy, bernardyn, dał nowy dach na kościele i ściany wyprostowat, a aparaty częścia ponaprawiat, częścia nowe wyżebrat. Obecnie zbiera ofiary na odmalowanie ottarzy i kościoła wewnatrz $[\ldots]^{42}$.

Kolejne prace remontowe przeprowadzono w 1886 r. Obejmowały one naprawę konstrukcji kościoła: [...] dano fundamenta nowe [...]. Przyciesie nowe $i$ bale podtożono nowe $w$ miejsce zgnitych. Podtoge potożono $w$ tafle nowa. W roku 1887 postawiona zostata w miejsce dawnej małej wieżyczki spróchniałej - nowa wieża wzniosła [...]. Wieżę tę budowat cieśla Tomasz Dunowicz mieszkaniec Szadku $[\ldots]^{43}$.

W późniejszych okresach wykonywano drobne naprawy i malowano wnętrze kościoła, co potwierdziły prowadzone niedawno prace konserwatorskie. W sporządzonym w 1931 r. inwentarzu kościoła czytamy np. Podłoge poprawiono w 1928 roku. Kościót wewnątrz catkowicie odnowiony i pomalowany wr. $1929[\ldots]^{44}$.

W czasie II wojny światowej wskutek wybuchu pocisku doszło do naruszenia bryły kościoła. Opis strat znajduje się w Ankiecie strat wojennych diecezji włocławskiej w l[atach] 1939/1945, gdzie czytamy: kościót uszkodzony częściowo - jeden wegiet od pocisku po str. Epistoty ${ }^{45}$. Prace zabezpieczające i naprawcze przeprowadzono w 1948 r., a później w latach 1957-195946. Wymieniono spróchniałe przyciesie w nawie i jednej z kaplic oraz zgrzybiałe belki ścian i desek stropowych. Drewniane lisice wymieniono na metalowe, przeprowadzono częściowy remont więźby dachowej oraz ankrowanie rozluźnionej konstrukcji ścian.

${ }^{41}$ Informacja zawarta w odkrytych w 1990 r. dokumentach znajdujących się w kopule wieży kościoła.

42 Korespondencja „Przeglądu Katolickiego”. Z diecezji kaliskiej, „Przegląd Katolicki” 1869, s. 604.

43 Pro memoriam, ks. Józef Mleczek, 6 XII 1887, kopia sporządzona przez ks. Tadeusza Miłka w 1990 r.

44 ADW, Akta parafii Rossoszyca (1920-1937), sygn. AKDWł, par. 174, s. 26.

45 ADW, Ankieta strat wojennych diecezji włocławskiej w $l[$ atach $] 1939 / 1945$, przeprowadzona przez archiwariusza diecezjalnego [ks. Stanisława Librowskiego] w r. 1947, t. 2, s. 263.

46 M. Pracuta, Ochrona zabytków na terenie województwa łódzkiego w latach 1945-1975, Łódź 2008, s. 85. 
Prace remontowe polegające na wymianie gontowego pokrycia dachowego na blaszane wykonano w $1991 \mathrm{r} .{ }^{47}$ Obecny wygląd wnętrza kościoła i jego wyposażenia jest efektem prac odświeżających przeprowadzonych w latach 1972-1993.

Ponieważ stan zabytkowego kościoła w Rossoszycy budził wiele zastrzeżeń, w 2012 r. mieszkańcy parafii postanowili podjąć działania mające na celu wykonanie gruntownego remontu świątyni. Zgodnie z zapisem protokołu nr 1/2012 z zebrania wiejskiego ${ }^{48}$, parafianie poprosili ówczesnego proboszcza, ks. Krzysztofa Czyżaka, o powołanie rady parafialnej i rozpoczęcie starań w sprawie remontu. Proboszcz jednak odmówił współpracy, tłumacząc to złym stanem zdrowia i zamiarem opuszczenia parafii. Pod naciskiem zebranych osób powołano Społeczną Komisję ds. Remontu Kościoła w Rossoszycy. Kolejnym krokiem było utworzenie Społecznego Komitetu Remontu Kościoła pw. św. Wawrzyńca w Rossoszycy ${ }^{49}$, który zainicjował zbiórkę pieniędzy wśród parafian $(20$ zł na miesiąc od rodziny, $10 \mathrm{zł}$ od osób samotnych) ${ }^{50}$. Zebrane fundusze wpłacano na otwarte konto bankowe. Zaangażowanie i determinacja społeczności lokalnej ostatecznie doprowadziła do podjęcia gruntownej renowacji rossoszyckiej świątyni.

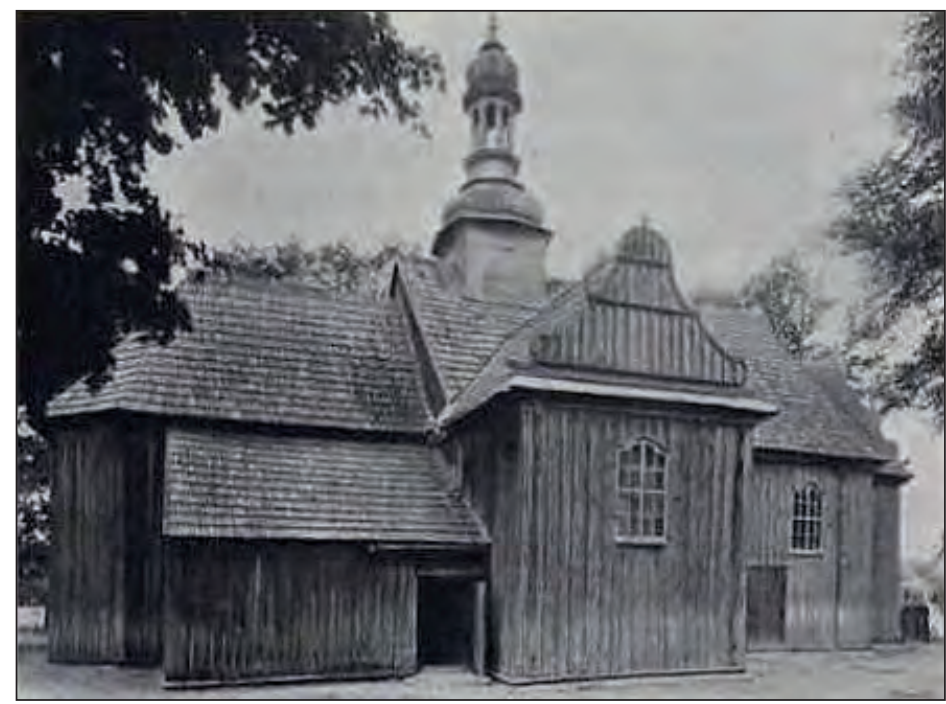

Fot. 2. Kościół w Rossoszycy (początek XX w.)

Źródło: http://www.kosciolydrewniane.pl/pages/drewnia9ne/rossosz.html;

Reprodukcja - ochrona zabytków sztuki - z. 1-4, Warszawa 1930-1931 [dostęp 23.03.2017]

47 Wojewódzki Konserwator Zabytków, Delegatura w Sieradzu, Karta ewidencyjna zabytku nieruchomego: Kościół parafialny pw. św. Wawrzyńca w Rossoszycy, zał. 1965, Wkładka do karty ewidencyjnej zabytków architektury i budownictwa, załącznik nr 1, zał. Andrzej Olszewski, 1986.

$48 \mathrm{http} / / /$ www.rossoszyca.pl, protokół z zebrania wiejskiego 1/2012 [dostęp 19.01.2017].

49 http://www.rossoszyca.pl, uchwała nr 1/2012 Społecznego Komitetu Remontu Kościoła w Rossoszycy z dnia 11.10.2012 r. w sprawie zatwierdzenia składu i funkcji Zarządu Komitetu [...] wybranego 21.09.2012 r. na czteroletnią kadencję/lub do zakończenia remontu kościoła [dostęp 19.01.2017].

${ }_{50} \mathrm{http}$ ///www.rossoszyca.pl, protokół nr 2/2012 z zebrania Społecznego Komitetu Remontu Kościoła pw. św. Wawrzyńca w Rossoszycy odbytego w dniu 11.10.2012 r. w Sali OSP w Rossoszycy [dostęp 19.01.2017]. 
Przy okazji remontu zostały odnalezione kopie dokumentów z 1784, 1860 oraz 1887 r. Dokument sporządzony 24 września 1784 r. upamiętnia końcowy etap budowy kościoła, jakim było zasadzenie bani z krzyżem na wieży przez wspomnianego wyżej budowniczego.
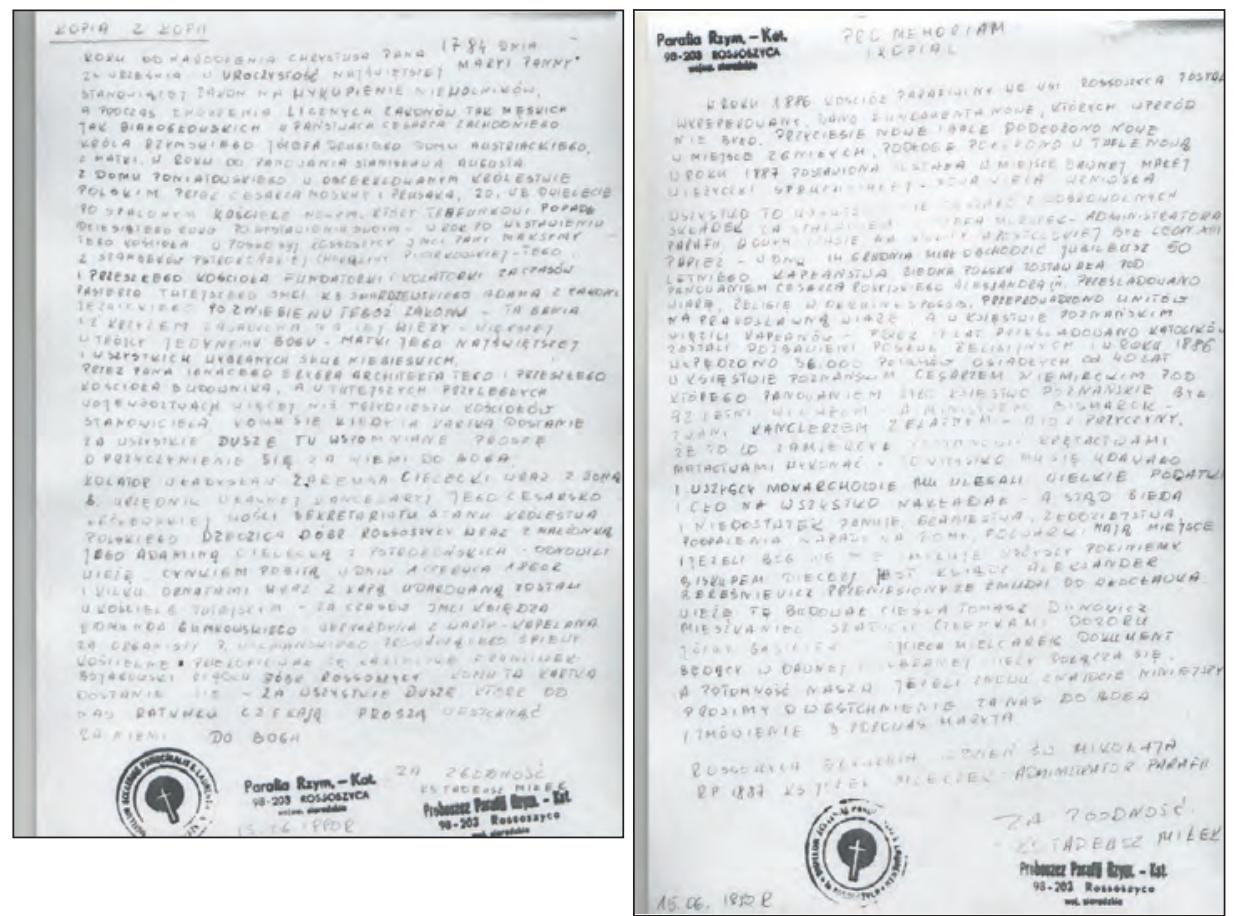

Fot. 3. Kopie dokumentów odnalezionych w wieży kościoła w Rossoszycy w 2016 r. Źródło: kopie dokumentów udostępnione przez proboszcza parafii ks. Mirosława Korytowskiego

\section{REMONT KOŚCIOŁA 2014-2017}

W 2014 r. rozpoczęto prace mające na celu gruntowny remont kościoła ${ }^{51}$ - pierwszy w tak szerokim zakresie od ponad stu lat. Celem tych prac jest rzetelna rekonstrukcja obiektu, przy użyciu najlepszych dostępnych materiałów budowlanych, z których podstawowym jest drewno modrzewiowe. W 2014 r. wymieniono zużytą konstrukcję dachu, naprawiono wiązanie, dach pokryto gontem (w miejsce wcześniejszego pokrycia blachą), wieżę pokryto blachą miedzianą. Wykonano także roboty ciesielskie związane z wymianą zużytych belek konstrukcyjnych ścian i uzupełniono ubytki w ścianach obwodowych. Podcięto podwaliny ścian

51 Zakres prac konserwatorsko-remontowych wykonanych przy kościele w Rossoszycy spisano na podstawie relacji obecnego proboszcza, ks. Mirosława Korytowskiego. 
i włożono blachę miedzianą w celu zapewnienia prawidłowej izolacji przed wilgocią. Wykonano nowe, zewnętrzne odeskowanie ścian, naprawiono drzwi i wymieniono okna. Wykonano nową instalację odgromową i odwodnieniową.

Wartość prac wykonanych w pierwszym roku remontu sięgała ogółem kwoty 328 tys. zł. Fundusze na ten cel pozyskano z dofinansowania Urzędu Marszałkowskiego Województwa Łódzkiego w kwocie 112 tys. zł, dofinansowania Gminy i Miasta Warta w kwocie 30 tys. zł oraz wpłat własnych parafian - 186 tys. zł.

W 2015 r. podjęto prace nad renowacją wnętrza kościoła - wyremontowano drewniane, kolebkowe sklepienia nad prezbiterium, traktem środkowym nawy i chórem oraz płaskie sklepienia nad kaplicami, traktami bocznymi nawy, kruchtą i zakrystią wraz z całym układem podpierających je słupów, belek i podciągów. Wykonano nowy, modrzewiowy sufit na całym kościele wraz ze sklepieniem kolebkowym w nawie głównej. Wymieniono całą podłogę, układając ją w kwadraty z desek modrzewiowych w obwódce dębowej. Oczyszczono ściany wewnętrzne, dokonano malowania konserwatorskiego belki tęczowej i renowacji znajdującego się tam krzyża, malowania konserwatorskiego łuków i słupów w nawie głównej. Dokonano renowacji wszystkich mosiężnych żyrandoli i kinkietów. Wymieniono całą instalację elektryczną (nowe przyłącze, tablica rozdzielcza, wyprowadzenie pod instalację antywłamaniową i przeciwpożarową), zamontowano halogeny doświetlające ołtarz główny i ołtarze boczne. Wykonano również renowację dzwonków i gongów, a także złocenie kielicha i puszki.

Wartość prac renowacji ścian i sufitu wyniosła 127 tys. zł, na co przeznaczono środki pochodzące z dofinansowania Urzędu Marszałkowskiego Województwa Łódzkiego w kwocie 60 tys. zł oraz z wpłat własnych parafian i darczyńców w kwocie 67 tys. zł. Koszt remontu podłogi wyniósł 125 tys. zł - pokryto go z dofinansowania Gminy i Miasta Warta w kwocie 30 tys. zł oraz ze składek parafian w kwocie 95 tys. zł.

W 2016 r. wykonano remont wewnętrznej strony ścian zrębowych oraz drewnianej konstrukcji chóru. Prace te wyceniono na kwotę 209 tys. zł - Ministerstwo Kultury i Dziedzictwa Narodowego przyznało wsparcie w kwocie 75 tys. zł, pozostałą część kosztów pokryto z wpłat własnych parafian (134 tys. zł). Natomiast konserwacja i restauracja gzymsów oraz arkad międzynawowych kosztowała 58 tys. zł - wojewódzki konserwator zabytków przyznał na ten cel 15 tys. zł, Gmina i Miasto Warta 20 tys. zł, a pozostałą część pokryto ze środków pochodzących z wpłat parafian (23 tys. zł).

W latach 2014-2016 na remont kościoła w Rossoszycy wydano łącznie kwotę 846 tys. zł, z czego 504 tys. zł stanowią środki pochodzące z wpłat parafian i darczyńców, 172 tys. zł dofinansowanie Urzędu Marszałkowskiego Województwa Łódzkiego, 80 tys. zł wsparcie Gminy Warta, 75 tys. zł dofinansowanie Ministerstwa Kultury i Dziedzictwa Narodowego, 15 tys. zł dofinansowanie Wojewódzkiego Konserwatora Zabytków.

Prace remontowe w kościele w Rossoszycy są kontynuowane, a ich zakres w 2017 r. obejmuje zakończenie prac związanych z instalacją elektryczną, instalacją niskoprądową, antywłamaniową, przeciwpożarową i nagłośnieniową. Du- 
żym wyzwaniem będzie planowane malowanie wnętrz kościoła. Na podstawie analizy starszych warstw malarskich próbuje się ustalić dawny wystrój wnętrza, jak również zidentyfikować stosowane niegdyś techniki malarskie. Stwierdzenie użycia bieli cynkowej (stosowanej od 1850 roku!) w najwcześniejszym odkrytym opracowaniu kolorystycznym drewnianych ścian i drewnianego pseudosklepienia kościoła (datowanego na 1783 r.) pozwala przypuszczać, że był on przez dłuższy czas bez opracowania barwnego lub pierwotne malatury nie zachowały się. W celu uniknięcia błędów popełnianych w przeszłości, wszystkie te prace przebiegają pod ścisłą kontrolą konserwatora zabytków (zadania tego podjęła się Monika Bystrońska-Kunat - specjalista w zakresie konserwacji malarstwa i rzeźby polichromowanej). Finalny etap prac konserwatorskich obejmie renowację rzeźb i obrazów znajdujących się w ołtarzach pozostających na wyposażeniu kościoła.

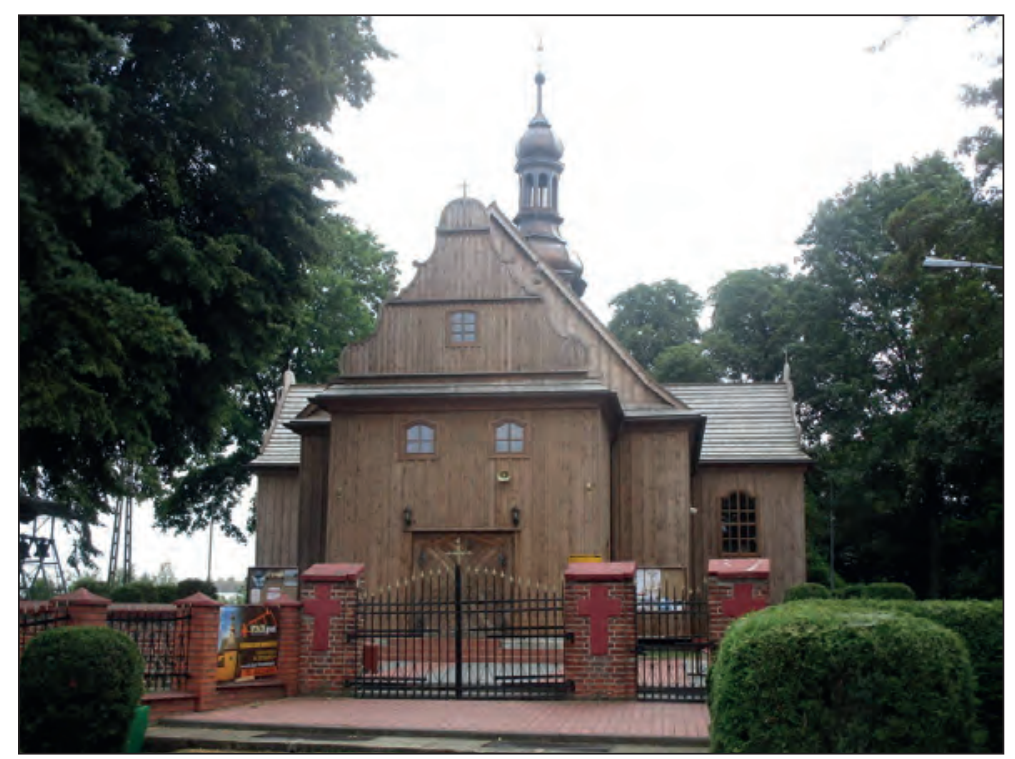

Fot. 4. Kościół w Rossoszycy w 2017 r.

Źródło: https://www.radiolodz.pl/posts/27460-milion-zlotych-na-kosciol-w-rossoszycy-pomogli-parafianie, zdjęcie Wojciech Muzal [dostęp 23.03.2017]

Przebieg dotychczasowych prac renowacyjnych oraz umiejętność pozyskania funduszy na ten cel pozwalają mieć pewność, że w niedługim czasie dzięki wysiłkowi i wytrwałym staraniom ks. Mirosława Korytowskiego, miejscowego proboszcza i społeczności lokalnej świątynia pw. św. Wawrzyńca odzyska dawny blask. Ich zmagania mogą być przykładem nie tylko udanej renowacji zabytkowego obiektu, lecz także świadectwem siły woli i dbałości o dziedzictwo kultury rossoszyckich parafian. 


\title{
ANEKS \\ Proboszczowie i administratorzy parafii pw. św. Wawrzyńca w XX w. ${ }^{52}$
}

\author{
ks. Marcin Makowski (1889-1903) \\ ks. Ignacy Pilich (1903-1924) \\ ks. Franciszek Jasiński (1924-1928) \\ ks. Stefan Petrykowski (1928-1931) \\ ks. Wacław Linowiecki (1931-1934) \\ ks. Adam Fijałkowski (1934-1941) \\ ks. Kazimierz Piosik (1945-1946) \\ ks. Józef Markowski (1946-1947) \\ ks. Aleksander Chrulewicz (1947-1960) \\ ks. Czesław Żurmanowicz (1960) \\ ks. Władysław Jach (1960) \\ ks. Marian Dławichowski (1960-1963) \\ ks. Eugeniusz Kręcicki (1963-1967) \\ ks. Władysław Łabiak (1967-1979) \\ ks. Kazimierz Paczkowski (1979-1987) \\ ks. Tadeusz Miłek (1987-1993) \\ ks. Zygmunt Głąbała (1993-1994) \\ ks. Henryk Piątkowski (1994-1996) \\ ks. Leszek Rybka (1996-2004) \\ ks. Krzysztof Czyżak (2004-2013) \\ ks. Mirosław Korytowski (2013- nadal)
}

\section{Bibliografia}

\section{Źródła archiwalne}

Archiwum Parafii Rzymskokatolickiej w Rossoszycy

Kopie dokumentów sporządzone w 1990 r. przez proboszcza parafii ks. Tadeusza Miłka, sygnowane za zgodność z oryginałem pieczęcią parafii, odnaleziono w 2014 r. podczas wymiany pokrycia dachowego na kościele.

Pro memoriam, ks. Józef Mleczek, 6 XII 1887, kopia sporządzona przez ks. Tadeusza Miłka w $1990 \mathrm{r}$.

Archiwum Diecezjalne we Włocławku

Akta parafii Rossoszyca (1920-1937), sygn. AKDWł par. 174.

Ankieta strat wojennych diecezji włocławskiej w l[atach]1939/1945, przeprowadzona przez archiwariusza diecezjalnego [ks. Stanistawa Librowskiego] w r. 1947, t. 2.

52 Wykaz proboszczów i administratorów kościoła w Rossoszycy znajduje się na stronie internetowej parafii, http://web.diecezja.wloclawek.pl/parafia/Rossoszyca/historia.php [dostęp 9.03.2017]. 
Archiwum Arcybiskupów Gnieźnieńskich

Mapa diecezji kujawsko-kaliskiej ułożona przez x. Bernarda Gratowskiego kapucyna w Zakroczymiu 1887 r.

Rubrycela dyecezyi kujawsko-kaliskiej z r. 1877, f. 54.

Wiz. 8, Acta visitationis Archidiaconatus Vnieioviensis [...] in anno Dni 1683-tio felicitier expeditae.

Wiz. 59, Opus biennale visitationum [generaliom] Archidiaconatus Vniejovien[sis] [...], Territorij Vielunensis, z lat 1761-1763.

Wiz. 73, Wizyta generalna do Decanatów Radomskiego, Brzeźnickiego i Lutomierskiego [w Archidiakonacie Uniejowskim] delegowanego wizytatora roku Pańskiego 1779 odprawiona.

Wiz. 80, Visitatio decanalis [...] in Decanatu Lutomiriensi, Archidiaconau Uniejoviensi existentium [...] per me [Vincentim Kepiński] anni 1786-ti expedita, facta et descripta.

Archiwum Państwowe w Łodzi Oddział w Sieradzu

Akta gminy Rossoszyca z lat 1945-1954 (zespół nr 24).

Narodowy Instytut Dziedzictwa

Rejestr zabytków nieruchomych, województwo łódzkie, nr rej. 839 z 28 grudnia 1967 r.

Wojewódzki Konserwator Zabytków Delegatura w Sieradzu

Karta ewidencyjna zabytku ruchomego, zał. Ewa Kozołup, 1993.

Karta ewidencyjna zabytku nieruchomego: kościół parafialny pw. św. Wawrzyńca w Rossoszycy, zał. 1965, Wkładka do karty ewidencyjnej zabytków architektury i budownictwa, załącznik nr 1, zał. Andrzej Olszewski, 1986.

\section{Źródła publikowane}

Dz.U. 1954, nr 43, poz. 191.

Dz.U. 1972, nr 49, poz. 312.

Główny Urząd Statystyczny w Warszawie: Województwa centralne i wschodnie Rzeczypospolitej Polskiej, podział na gminy według stanu z dnia 1 IV 1933 roku, Książnica - Atlas, Lwów 1933.

Katalog zabytków sztuki w Polsce, t. II: Województwo łódzkie, red. J. Łoziński, z. 10, Warszawa 1953.

Łaski J., Liber beneficiorum archidioecesis gnesnensis, t. 1, oprac. J. Łukowski, J. Korytkowski, Gniezno 1880-1881.

Podziat Administracyjny Polski Ludowej, Urząd Rady Ministrów, Biuro do Spraw Prezydiów Rad Narodowych, Warszawa 1956.

Słownik geograficzny Królestwa Polskiego, red. B. Chlebowski, W. Walewski, Warszawa 1888 , t. IX.

\section{Opracowania}

Aleksandrowicz M., Gnieźnieńska Archidiecezja. Organizacja terytorialna. Dekanaty, [w:] Encyklopedia Katolicka, t. 5, Lublin 1989. 
Bogusławski R., Tajemniczy portret - przyczynek do biografii starosty Szadkowskiego Franciszka Budzisz-Pstrokońskiego, „Biuletyn Szadkowski” 2007, t. 7.

Encyklopedia Kościelna podtug teologicznej encyklopedii Wetzera i Weltego z licznymi jej dopetnieniami wydana przez x. Michała Nowodworskiego, t. 32, Płock 1913.

Gąsiorowski A., Urzędnicy województw tęczyckiego i sieradzkiego XVI-XVIII w. Spisy, Kórnik 1993.

Kumor B., Ustrój i organizacja Kościoła polskiego w okresie niewoli narodowej (17721918), Kraków 1980.

Librowski S., Repertorium akt wizytacji kanonicznych dawnej Archidiecezji Gnieźnieńskiej, cz. 1: Akta przechowywane w Archiwum Diecezjalnym we Włocławku, z. 3: Archiwa Biblioteki i Muzea Kościelne, t. 30.

Migasiewicz P., Dzieła rzébiarza Franza Eytnera na terenie dawnych ziem łęczyckiej i sieradzkiej, [w:] Sztuka Polski Środkowej. Studia V, red. P. Gryglewski, E. Kubiak, K. Stefański, Łódź 2011.

Niesiecki K., Herbarz Polski. Dodatek do Herbarza Polskiego, Lipsk 1839-1846.

Pracuta M., Ochrona zabytków na terenie województwa łódzkiego w latach 1945-1975, Łódź 2008.

„Przegląd Katolicki” 1869.

„Rocznik Diecezji Włocławskiej” 1991, 2001.

Ruszkowski A., Sieradz i okolice, Sieradz 2000.

Słownik terminologiczny sztuk pięknych, red. S. Kozakiewicz, Warszawa 1969.

Ulanowski B., Wizytacje dóbr arcybiskupstwa gnieźnieńskiego i kapituły gnieźnieńskiej z XVI wieku, Kraków 1920.

Zdzitowiecki S., Rozporzadzenia diecezjalne. 1. Nowy podział dekanatów, „Kronika Diecezji Kujawsko-Kaliskiej” 1917, nr 1.

\section{Strony internetowe}

http://www.rossoszyca.pl [dostęp 19.01.2017].

http://www.kosciolydrewniane.pl/pages/drewniane/rossosz.html [dostęp 23.03.2017].

http://www.radiolodz.pl/posts/27460-milion-zlotych-na-kosciol-w-rossoszycy-pomo-

gli-parafianie [dostęp 23.03.2017].

http://web.diecezja.wloclawek.pl/parafia/rossoszyca/historia.php [dostęp 9.03.2017].

[Wpłynęło: marzec; poprawiono: czerwiec 2017 r.]

\section{THE CHURCH OF ST. LAWRENCE IN ROSSOSZYCA - THE HISTORY AND THE PRESENT STATE}

\section{Summary}

The parish church of St. Lawrence in Rossoszyca, built of larch wood at the end of the 18th century, is one of the most valuable historical monuments in the Szadek region. Over the past two hundred years it was renovated many times. The year 2016 was the 
600 anniversary of the establishment of the Rossoszyca parish, which gave an impulse for undertaking in 2014 yet another, thorough renovation of the church, which is still going on. The present church building is the third one erected in this location. The first one existed in 1770-1773, to be replaced by another church, which burnt down in 1781 . The third building, erected in 1783, has survived until today. Apart from the history of the church, the article outlines the restoration work carried out since 2014.

Keywords: the parish of Rossoszyca, the village of Rossoszyca, the Church of St. Lawrence in Rossoszyca. 